\title{
Morphology of the Pterion in Serbian Population
}

\author{
Morfología del Pterion en Población Serbia
}

\author{
Knezi Nikola ${ }^{1}$; Stojsic Dzunja Ljubica ${ }^{1}$; Adjic Ivan²; Maric Dusica ${ }^{1}$ \& Pupovac Nikolina $^{4}$
}

KNEZI, N.; STOJSIC, D. L.; ADJIC, I.; MARIC, D. \& PUPOVAC, N. Morphology of the pterion in Serbian population. Int. J. Morphol., 38(4):820-824, 2020.

SUMMARY: The pterion is a topographic point on the lateral aspect of the skull where frontal, sphenoid, parietal and temporal bones form the $\mathrm{H}$ or $\mathrm{K}$ shaped suture. This is an important surgical point for the lesions in anterior and middle cranial fossa. This study was performed on 50 dry skulls from Serbian adult individuals from Department of Anatomy, Faculty of Medicine in Novi Sad. The type of the pterion on both sides of each skull was determined and they are calcified in four types (sphenoparietal, frontotemporal, stellate and epipteric). The distance between the center of the pterion and defined anthropological landmarks were measured using the ImageJ software. Sphenoparietal type is predominant with $86 \%$ in right side and $88 \%$ in left side. In male skulls, the distance from the right pterion to the frontozygomatic suture is $39.89 \pm 3.85 \mathrm{~mm}$ and $39.67 \pm 4.61 \mathrm{~mm}$ from the left pterion to the frontozygomatic suture. In female skulls the distance is $37.38 \pm 6.38 \mathrm{~mm}$ on the right and $35.94 \pm 6.46 \mathrm{~mm}$ on the left. The shape and the localization of the pterion are important because it is an anatomical landmark and should be used in neurosurgery, traumatology and ophthalmology.

KEY WORDS: Morphology; Morphometry; Human skull; Pterion.

\section{INTRODUCTION}

The pterion (known as the Sylvian point) is an anthropological landmark in the lateral aspect of the human skull at the bottom of temporal fossa. In this point, squamous part of frontal bone, sphenoid angle of parietal bone, squama of the temporal bone and greater wing of sphenoid bone meet and form the irregular $\mathrm{H}$ or $\mathrm{K}$ shaped suture. The pterion is formed with mesenchymal ossification of anterolateral fontanelle of neonatal skull, which closes at the third month after birth (Standring et al., 2016).

In 1875, Broca (1875) classified three types of pterion (sphenoparietal, frontotemporal and stellate). In 1956, Murphy (1956) (Fig. 1) expanded the list with another type; the epipteric. In the sphenoparietal type the sphenoid and parietal bones touch directly and form the suture, without the frontal and temporal bones making contact with one another. In the frontotemporal type the frontal and temporal bones touch directly and form the suture, without the sphenoid and parietal bones making contact with one another. In the stellate type frontal, parietal, sphenoid and temporal bones conect together at one point. The characteristic of the epipteric type are the Wormian bones or sutural bones between the frontal, parietal, sphenoid and temporal bones. Wang et al. in 2006, added zygomaticoparietal (a variation of the sphenoparietal type) and zygomaticotemporal types (a variation of the frontotemporal type) to the original four.

The pterion is a significant landmark for age and sex determination of the human skull (skeleton) in the archeology and forensic medicine (Lovejoy et al., 1985). Saxena et al. (2003) talk about how pterional approach is important for the lesions in Broca's area (44-45), the insula and the stem of the lateral sulcus and after the 1970s, pterional approach became the gold standard for lesions in the sellar and supsellar region, circle of Willis, Sylvian fissure and superior portion of the clivus (Andrade-Barazarte et al., 2019). Skull fracture in the pterion region can damage frontal branch of middle meningeal artery and cause extradural hematoma (Lama \& Mottolese, 2000), while the different types of the pterion can also confuse the clinicians during diagnosis of the lateral skull fractures in emergency conditions (Morales Ávalos et al., 2011).

\footnotetext{
${ }^{1}$ University of Novi Sad, Faculty of Medicine, Department of Anatomy, Serbia.

${ }^{2}$ Oncology Institute of Vojvodina, Sremska Kamenica, Serbia.

${ }^{3}$ University of Novi Sad, Faculty of Medicine, Serbia.

${ }^{4}$ University of Novi Sad, Faculty of Medicine, Department of Ophthalmology, Serbia.
} 


\section{MATERIAL AND METHOD}

The study consists of 50 adult dry skulls ( 22 male and 28 female) which were obtained from Department of Anatomy, Faculty of Medicine in Novi Sad, Serbia. Specimens with observable defects or congenital anomalies were excluded from the study. Approval from the Institutional Ethics committee was given for the study.

The type of the pterion was determined based on description (sphenoparietal, frontotemporal, stellate and epipteric types) by Murphy.

After determining the pterion type, the skulls were photographed with a Nikon D3400. A software program for morphometric measurement, ImageJ $1.48 \mathrm{v}$, was used for photo analysis. Morphometric analysis included: PSFZ - Distance from the center of the pterion to the anterior aspect of the frontozygomatic suture; PZAN - Distance from the center of the pterion to the zygomatic angle; PZA - Distance from the center of the pterion to the zygomatic arch; PH - Distance from the center of the pterion to the Henle's spine; PMP - Distance from the center of the pterion to the mastoid process of the temporal bone; PI - Distance from the center of the pterion to the inion (Fig. 2).

The Windows Excel program was used for statistical analysis of measurements. Comparison of average values for the groups was conducted using Student t-test, and statistical significance determined at $\mathrm{p}<0.05$.

\section{RESULTS}

In our study we observed two types of the pterion (Table I). The most common type was sphenoparietal in both population (18/21 in males, $25 / 23$ in females), and the second was epipteric type (4/1 in males, $3 / 5$ in females).

The means and standard deviation of the linear measurements taken from the pterion are presented in Table II. The analysis showed that there are some differences in the measured parameters within sex examined skulls. Statistically significant difference $(\mathrm{p}<0.05)$ was observed in the distance from pterion to Henle's spine, pterion and mastoid process of the temporal bone in the male skulls. Also, in the female statistically significant difference $(\mathrm{p}<0.05)$ was observed in the distance from pterion to mastoid process of the temporal bone and from pterion to inion in female skulls.

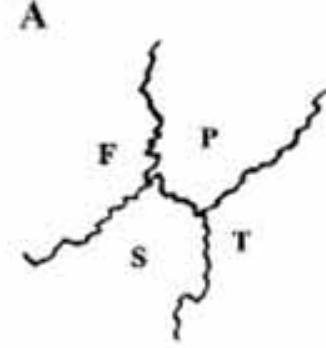

C

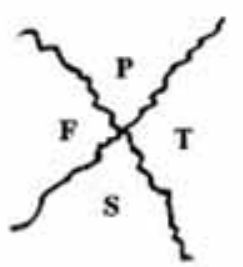

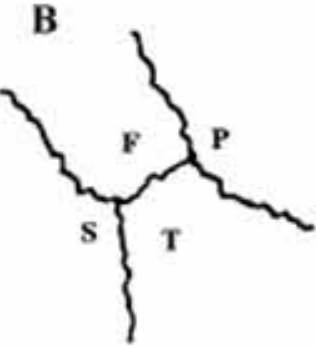

D

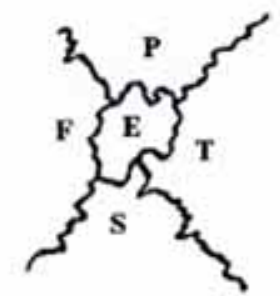

Fig. 1. Types of pterions by Murphy; A: Sphenoparietal; B: Frontotemporal; C: Stellate; D: Epipteric;(F-frontal bone, P-parietal bone, T-temporal bone, S-sphenoid bone, E-epipteric bone).

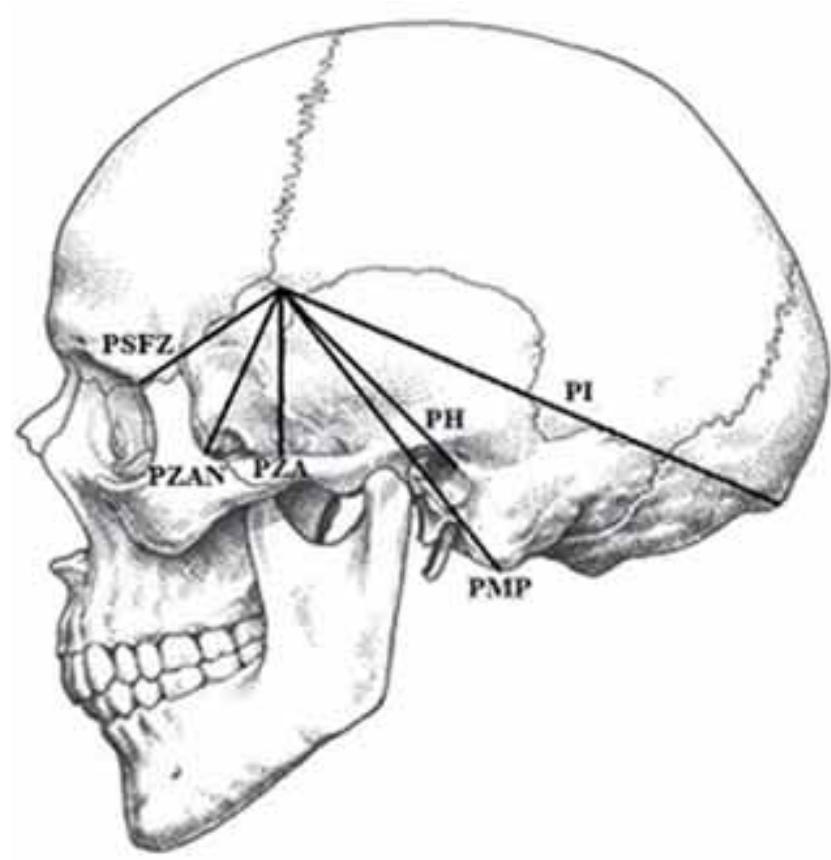

Fig. 2. Morphometric parameters taken on each skull (Hansen, 2018). (PSFZ - Distance from the center of the pterion to the anterior aspect of the frontozygomatic suture; PZAN - Distance from the center of the pterion to the zygomatic angle; PZA Distance from the center of the pterion to the zygomatic arch; $\mathrm{PH}$ - Distance from the center of the pterion to the Henle's spine; PMP - Distance from the center of the pterion to the mastoid process of the temporal bone; PI - Distance from the center of the pterion to the inion) 
Table I. Number and percentage distribution of pterion type on the examined skulls in relation to the side and sex.

\begin{tabular}{lcccccccccccc}
\hline & \multicolumn{4}{c}{ Male } & \multicolumn{4}{c}{ Female } & \multicolumn{3}{c}{ Total } \\
& \multicolumn{2}{c}{ Right } & \multicolumn{2}{c}{ Left } & \multicolumn{2}{c}{ Right } & Left & \multicolumn{2}{c}{ Right } & Left \\
\cline { 2 - 15 } & $\mathrm{n}$ & $\%$ & $\mathrm{n}$ & $\%$ & $\mathrm{n}$ & $\%$ & $\mathrm{n}$ & $\%$ & $\mathrm{n}$ & $\%$ & $\mathrm{n}$ & $\%$ \\
Sphenoparietal type & 18 & 81.8 & 21 & 95.5 & 25 & 89.3 & 23 & 82.1 & 43 & 86 & 44 & 88 \\
Epipteric type & 4 & 18.2 & 1 & 4.5 & 3 & 10.7 & 5 & 17.9 & 7 & 14 & 6 & 12 \\
\hline
\end{tabular}

Table II. Results of the measured distances between the pterion and specific topographical points.

\begin{tabular}{ccccccc}
\hline & \multicolumn{2}{c}{ Male } & \multicolumn{4}{c}{ Female } \\
& Right & Left & & Right & Left \\
& Mean \pm SD & Mean \pm SD & $p$ & Mean \pm SD & Mean \pm SD & $p$ \\
\hline PSFZ & $39.98 \pm 3.85$ & $39.67 \pm 4.61$ & 0.38 & $37.38 \pm 6.38$ & $35.94 \pm 6.46$ & 0.08 \\
PZAN & $43.93 \pm 4.16$ & $41.41 \pm 2.43$ & 0.09 & $42.03 \pm 6.82$ & $39.76 \pm 6.35$ & 0.15 \\
PZA & $42.48 \pm 4.18$ & $39.23 \pm 1.98$ & 0.06 & $38.61 \pm 5.43$ & $37.57 \pm 5.35$ & 0.18 \\
PH & $53.13 \pm 2.22$ & $50.96 \pm 2.15$ & 0.02 & $47.74 \pm 5.12$ & $46.79 \pm 5.09$ & 0.23 \\
PMP & $78.47 \pm 4.12$ & $74.83 \pm 5.60$ & 0.02 & $70.23 \pm 6.84$ & $67.43 \pm 7.02$ & 0.03 \\
PI & $85.64 \pm 6.40$ & $86.31 \pm 8.43$ & 0.07 & $80.60 \pm 8.15$ & $77.08 \pm 8.77$ & 0.01 \\
\hline
\end{tabular}

PSFZ: pterion - anterior aspect of frontozygomatic suture; PZAN: pterion - zygomatic angle; PZA: pterion - zygomatic arch; PH: pterion - Henle's spine; PMP: pterion - mastoid process of the temporal bone; PI pterion - inion.

\section{DISCUSSION}

The pterion is an important anatomical landmark for neurosurgical and neurovascular interventions with the pterional approach (Rodriguez Rubio et al., 2019). The morphological and morphometric variations of the pterion have been detected in various populations. Pterion type is subject to evolutionary, ethnic and regionalvariations. Wang et al. (2006), describe enviromental and genetic factors (MSX2 genehomeodmain transcription factor).

The sphenoparietal type is dominant in human skulls while the frontotemporal is dominant in nonhuman primates (Seema \& Mahajan, 2014). Morphological analysis in our study of 50 human dry skulls confirms the theory about dominance of the sphenoparietal type of the pterion. The study demonstrated a prevalence of $86 \%$ of the sphenoparietal type in the right side and $88 \%$ in the left side. While the incidence of epipteric type is $14 \%$ in right side and $12 \%$ in left side. The frontotemporal and stellate types were not found in our study.

Also, some authors studied different populations to determine the most common pterion types, as can be seen in Table III. Ilknur et al. (2009), observed pterion types of human skulls from the 13 th and 20th century. The sphenoparietal type of the pteron was dominant in both groups $(87.5 \%$ from 13 th and $89.2 \%$ from 20th century). Frontotemporal $(6.25 \%$ from 13 th and $3.6 \%$ from 20 th century) and epipteric type $(6.25 \%$ from 13 th and $3.6 \%$ from 20th century) were also observed in this study, but stellate type was only detected in group from the 20th century. In the study of Sudha et al. (2013), in South Indian population analysis on pterion type, sphenoparietal type was the most common (80\%), followed by frontotemporal (11.3 $\%)$, stellate $(5.3 \%)$, and epipteric $(3 \%)$.

In our study, a variation of the epipteric type was also found, in which one small irregular shaped epipteric bone was inserted within the pterion on one or both sides. The number of these small bones can vary. Satheesha \& Soumya (2008) in a case report published in 2008, discribe a multi-epipteric type of the pterion, in which 4 small irregular shaped epipteric bones represent the highest number documented. This type is thought to occur in children with hydrocephalus, where it can complicate the neurosurgical intervention (Natekar et al., 2011).

Does the distance between pterion and anthropological points have different values just because of sex, age or race? While pterion type is influenced by race and ethnicity, methodology of the studies may contribute differences to the observed measurement parameters. In our study the distances from pterion to anthropological points are measured on the photographs of skulls, using the software program ImageJ. The distance between pterion and anterior aspect of the frontozygomatic suture in our study is $39.98 \pm 3.85 \mathrm{~mm}$ on the right and $39.67 \pm 4.61 \mathrm{~mm}$ on left side in male skulls whilethis distance is $37.38 \pm 6.38 \mathrm{~mm}$ on the right and $35.94 \pm 6.46$ on the left side in female skulls. 
Table III. Comparison of different studies.

\begin{tabular}{|c|c|c|c|c|}
\hline & $\begin{array}{c}\text { Sphenoparietal } \\
\text { type }(\%)\end{array}$ & $\begin{array}{c}\text { Frontotemporal } \\
\text { type ( \%) }\end{array}$ & $\begin{array}{l}\text { Epipteric } \\
\text { type (\%) }\end{array}$ & $\begin{array}{l}\text { Stellate } \\
\text { type ( \%) }\end{array}$ \\
\hline Saxena et al. (2003) Indian, both sexes & 84.72 & 10.01 & - & 5.17 \\
\hline Ilknur et al. (2009) Byzantine period, male & 87.5 & 6.25 & - & - \\
\hline Ilknur et al. (2009) Contemporary period, sex unknown & 89.2 & 3.6 & - & 3.6 \\
\hline Sudha et al. (2013) South Indian, sex unknown & 80 & 3 & 11.3 & 5.3 \\
\hline A ksu et al. (2014) West Anatolian region, sex unknown & 85.2 & 1.1 & 5.5 & 8.2 \\
\hline Chaijaroonkhanarak et al. (2017) Thai, both sexes & 93.61 & 4.26 & 2.13 & - \\
\hline Dutt et al. (2017), India, sex unknown & 82.7 & 3.20 & 11.54 & 2.56 \\
\hline Nayak et al. (2017) India, sex unknown & 85 & 10 & - & 5 \\
\hline Modasiya et al. (2018) Gujarat region, sex unknown & 80.9 & - & 8.18 & 10.9 \\
\hline Present study - right side, both sexes & 86 & - & 14 & - \\
\hline Present study - left side, both sexes & 88 & - & 12 & - \\
\hline
\end{tabular}

Mwachaka et al. (2008) used a Manutan ${ }^{\circledR}$ digital vernier caliper with an accuracy of $0.001 \mathrm{~mm}$. Using this methodology, the results obtained are smaller than the results of this study. The distance between pterion and posterior aspect of the frontozygomatic suture among male Kenyans (using a Manutan ${ }^{\circledR}$ digital vernier caliper with an accuracy of $0.001 \mathrm{~mm}$ ) is $30.73 \pm 3.74 \mathrm{~mm}$ and females $29.74 \pm 3.41$ $\mathrm{mm}$. This study also describes the distance between pterion and posterior aspect of the frontozygomatic suture, which is on the right side $30.35 \pm 3.40 \mathrm{~mm}$ and $30.34 \pm 4.30 \mathrm{~mm}$ on the left side.

Similar values were found in the study done in Nigeria using a manual vernier caliper where it was reported that distance between pterion and frontozygomatic suture is $31.87 \pm 0.642 \mathrm{~mm}$ in males, and $30.35 \pm 0.8358 \mathrm{~mm}$ in females. Also in the same study the distance is $31.52 \pm 0.677 \mathrm{~mm}$ in right side and $30.82 \pm 0.809 \mathrm{~mm}$ in left side (Adejuwon et al., 2013).

KNEZI, N.; STOJSIC, D. L.; ADJIC, I.; MARIC, D. \& PUPOVAC, N. Morfología del pterion en población serbia. Int. J. Morphol., 38 (4):820-824, 2020.

RESUMEN: El pterion es un punto topográfico en la cara lateral del cráneo donde los huesos frontales, esfenoides, parietales y temporales forman la sutura en forma de $\mathrm{Ho}$ K. Este es un punto quirúrgico importante para las lesiones en la fosa craneal anterior y media. Este estudio se realizó en 50 cráneos secos de adultos serbios del Departamento de Anatomía de la Facultad de Medicina de Novi Sad. Se determinó el tipo de pterión en ambos lados de cada cráneo y se calcifican en cuatro tipos (esfenoparietal, frontotemporal, estrellado y epipterico). La distancia entre el centro del pterion y los puntos de referencia antropológicos definidos se midió utilizando el software ImageJ. El tipo esfenoparietal es predominante con $86 \%$ en el lado derecho y $88 \%$ en el lado izquierdo. En los cráneos masculinos, la distancia desde el pterion derecho hasta la sutura frontocigomática es $39,89 \pm 3,85 \mathrm{~mm}$ y $39,67 \pm 4,61 \mathrm{~mm}$ desde el pterion izquierdo hasta la sutura frontocigomática. En los cráneos femeninos, la distancia es 37,38 $\pm 6,38 \mathrm{~mm}$ a la derecha y $35,94 \pm 6,46 \mathrm{~mm}$ a la izquierda. La forma y la localización del pterion son importantes debido a que es un indicador anatómico y debe usarse en neurocirugía, traumatología y oftalmología.

PALABRAS CLAVE: Morfología; Morfometria; Cráneo humano; Pterion.

\section{REFERENCES}

Adejuwon, S. A.; Olopade, F. E. \& Bolaji, M. Study of the location and morphology of the pterion in adult nigerian skulls. ISRN Anat., 2013:403937, 2013.

Aksu, F.; Akyer, S. P.; Kale, A.; Geylan, S. \& Gayretli, O. The localization and morphology of pterion in adult West Anatolian skulls. $J$. Craniofac. Surg., 25(4):1488-91, 2014.

Broca, P. Instructions craniologiques et craniometriques. Mem. Soc. Anthrop., 2:1-203, 1875.

Chaijaroonkhanarak, W.; Woraputtaporn, W.; Prachaney, P.; Amarttayakong, P.; Khamanarong, K.; Pannangrong, W.; Welbat, J. U. \& Iamsaard, S. Classification and incidence of pterion patterns of thai skulls. Int. J. Morphol., 35(4):1239-42, 2017.

Dutt, V.; Shankar, V. V. \& Shetty, S. Morphometric study of pterion and asterion in adult human skulls of Indian origin. Int. J. Anat. Res., 5(2.2):3837-42; 2017.

Hansen, J. T. Netter's Anatomy Coloring Book. $2^{\text {nd }}$ ed. New York, Elsevier, 2018.

Ilknur, A.; Mustafa, K. I. \& Sinan, B. A comparative study of variation of the pterion of human skulls from 13th and 20th century Anatolia. Int. J. Morphol., 27(4):1291-8, 2009.

Lama, M. \& Mottolese, C. Middle meningeal artery aneurysm associated with meningioma. J. Neurosurg. Sci., 44(1):39-41, 2000.

Lovejoy, C. O.; Meindel, R. S.; Mensforth, R. P. \& Barton, T. J. Multifactorial determination of skeletal age at death: a method and blind tests of its accuracy. Am. J. Phys. Anthropol., 68(1):1-14, 1985.

Modasiya, U. P. \& Kanani, S. D. Study of pterion and asterion in adult human skulls of north Gujarat region. Indian J. Clin. Anat. Physiol., 5(3):353-6, 2018.

Morales Ávalos, R.; Elizondo Alvarado, M.; Elizondo Omaña, R. E. \& Guzmán López, S. Estudio morfológico del pterion y asterion en cráneos adultos mexicanos. Rev. Argent. Anat. Clin., 3(3):77-83, 2011. 
Murphy, T. The pterion in the Australian aborigine. Am. J. Phys. Anthropol., 14(2):225-44, 1956.

Mwachaka, P.; Hassanali, J. \& Odula P. Anatomic position of the pterion among kenyans for lateral skull approaches. Int. J. Morphol., 26(4):9313, 2008.

Natekar, P. E.; DeSouza, F. M. \& Natekar, S. P. Pterion: An anatomical variation and surgical landmark. Indian J. Otol., 17(2):83-5, 2011.

Nayak, G.; Mohanty, B. B. \& Das, S. R.; Morphometric study of pterion and its clinical significance. Asian J. Pharm. Clin. Res., 10(10):142-4, 2017.

Rodriguez Rubio, R.; Chae, R.; Vigo, V.; Abla, A. A. \& McDermott, M., Immersive surgical anatomy of the pterional approach. Cureus, 11(7):e5216, 2019.

Satheesha, N. B. \& Soumya, K. V. Usual sutural bones at pterion. IJAV, 1:19-20, 2008.

Saxena, R. C.; Bilodi, A. K.; Mane, S. S. \& Kumar, A. Study of pterion in skulls of Awadh area--in and around Lucknow. Kathmandu Univ. Med. J. (KUMJ), 1(1):32-3, 2003.

Seema \& Mahajan, A. Pterion formation in North Indian population: an anatomico-clinical study. Int. J. Morphol., 32(4):1444-8, 2014.

Standring, S. Gray's Anatomy. The Anatomical Basis of Clinical Practice. $41^{\text {st }}$ ed. New York, Elsevier, 2016.

Sudha, R.; Sridevi, C. \& Ezhilarasi, M. Anatomical variations in the formation of pterion and asterion in South Indian population. Int. J. Curr. Res. Rev., 5(9):92-101, 2013.

Wang, Q.; Opperman, L. A.; HavilL, L. M.; Carlson, D. S. \& Dechow, P. C. Inheritance of sutural pattern at the pterion in Rhesus monkey skulls. Anat. Rec. A Discov. Mol. Cell Evol. Biol., 288(10):1042-9, 2006.
Corresponding author:

Knezi Nikola MD

Teaching Assistant, PhD student

University of Novi Sad

Faculty of Medicine

Department of Anatomy

Veljkova 3

Novi Sad 21000

SERBIA

Email: nikola.knezi@mf.uns.ac.rs

Received: 22-01-2020

Accepted: 02-03-2020 